\title{
Transport spectroscopy of confined fractional quantum Hall systems
}

\section{Doctoral Thesis}

Author(s):

Baer, Stephan

Publication date:

2014

Permanent link:

https://doi.org/10.3929/ethz-a-010252603

Rights / license:

In Copyright - Non-Commercial Use Permitted 
DISS. ETH NO. 22223

\title{
Transport spectroscopy of confined fractional quantum Hall systems
}

\author{
(Dr. sc. ETH Zurich) \\ presented by \\ Stephan Baer \\ MSc ETH Physics \\ born on 17.08.1984 \\ citizen of Germany
}

A thesis submitted to attain the degree of DOCTOR OF SCIENCES of ETH ZURICH

accepted on the recommendation of:

Prof. Dr. Klaus Ensslin, examiner

Prof. Dr. Thomas Ihn, co-examiner

Prof. Dr. Bernd Rosenow, co-examiner

Prof. Dr. Werner Wegscheider, co-examiner 


\section{Abstract}

At very low temperatures and at certain filling factors $\nu$, the ground state of a high mobility electron gas exposed to a strong magnetic field becomes incompressible, forming an integer quantum Hall $(\mathrm{IQH})$ or fractional quantum Hall $(\mathrm{FQH})$ state. The $\nu=5 / 2$ state is one of the most exceptional of these states, as it is believed to exhibit non-Abelian quasiparticle excitations. This property makes it not only interesting from a fundamental physics point of view, but also for possible applications in topological quantum computing.

In this thesis, we investigate the properties of the IQH and FQH states, using transport measurements in the bulk, in quantum point contacts (QPCs) and through quantum dots (QDs) or interferometers. One important goal of this thesis has been to study the properties of the $\nu=5 / 2$ state by investigating its tunneling and confinement properties and to make progress towards the realization of an experiment that allows to probe the statistics of the quasiparticle excitations at $\nu=5 / 2$.

In the first part of this thesis, we review the fundamentals of two-dimensional electron gases and quantum Hall physics and the most important theoretical and experimental findings on the $\nu=5 / 2$ state (Part I).

Then we discuss (Part II) experimental challenges that had to be overcome in order to conduct the experiments presented here. For this, a dilution refrigerator setup and the sample fabrication had to be optimized, and a new low temperature filtering setup has been designed and built. Accomplishing this allowed us to observe a fully gapped $\nu=5 / 2$ FQH state and to reach electronic temperatures as low as $12-13 \mathrm{mK}$.

Confining FQH states to QPCs allows investigating their tunneling properties and is a crucial step for successfully implementing interference experiments. Transport properties of QPCs are discussed in Part III of this thesis. Without applying a magnetic field, we study finite bias transport in clean QPCs and characterize the confinement potential. As the magnetic field strength is increased and the QPC transmission is varied, different (fractional) quantum Hall states can be formed in the QPCs. We discuss the importance of disorder and localization and its influence on the transport properties of QPCs in the IQH and FQH regime. By identifying the most suitable growth and doping schemes and using optimized gating techniques, we demonstrate how QPCs can be defined without destroying the most fragile FQH states, like the $\nu=5 / 2$ state. Making use of these techniques, we finally investigate weak quasiparticle tunneling in the FQH states of the second Landau level. The bias and temperature dependence of the quasiparticle tunneling conductance allows us to extract parameters that describe the edge excitations of the FQH states at $\nu=5 / 2,7 / 3$ and $8 / 3$. This allows a comparison with theoretically predicted candidate wavefunctions for these states. At $\nu=5 / 2$, best agreement is found with the Abelian $(3,3,1)$ - and $(1,1,3)$-states, while a particle-hole conjugate Laughlin state is the best fit for the tunneling experiments at $\nu=8 / 3$.

Proceeding to structures of enhanced complexity, we then investigate the properties of QDs and interferometers in the IQH and FQH regime (Part IV). We demonstrate how charge detection techniques can be pushed towards the technical limit, in order to investigate time-resolved single-electron tunneling in micron-sized QDs which are suitable for interference experiments. In the case of pinched-off tunneling barriers, a situation can arise in which the internal structure of the QD with compressible and incompressible re- 
gions modifies the charging spectrum. We show how such a situation can be understood in analogy to the physics of a double QD. In a more open regime with a large transmission of the tunneling barriers, the system behaves like a Coulomb-dominated Fabry-Pérot interferometer. Finally, we show the progress that has been made towards the realization of a Fabry-Pérot interferometer at $\nu=5 / 2$. We have investigated top-gated structures defined on three different wafers, which were fabricated using different growth and doping techniques. We discuss experimental challenges and limitations that arise due to the gating of these high-mobility structures. Using an optimized illumination and gating procedure, we succeed to define an interferometer with $950 \mathrm{~nm}$ wide QPCs, which exhibits a perfect transmission of the $\nu=5 / 2$ state with an energy gap exceeding $200 \mathrm{mK}$. This demonstrates, that the $\nu=5 / 2$ state remains fully gapped in the center of our interferometer. Though no interference at $\nu=5 / 2$ could be observed in the samples in study, our results might lead the way to an experimental realization of a Fabry-Pérot interferometer at $\nu=5 / 2$.

At last we discuss bulk transport measurements in the reentrant integer quantum Hall (RIQH) phases of the second Landau level (Part V). In non-equilibrium transport where a large DC current of several $\mathrm{nA}$ is applied, transitions from RIQH phases to an isotropic compressible phase are observed. From this transition, we extract characteristic energy scales for the different RIQH states. Surprisingly, the transition from the RIQH phases to the isotropic compressible phase is qualitatively different for less than half-filled and more than half-filled spin branches. This possibly indicates either a breaking of the electron-hole symmetry or a more complex structure of the RIQH states than currently anticipated by theory.

Our results give an important insight in the physics of the second Landau level and contribute to the understanding of the FQH states at $\nu=5 / 2,7 / 3$ and $8 / 3$. 


\section{Zusammenfassung}

Der Grundzustand eines hochbeweglichen Elektronengases das einem starken Magnetfeld und tiefen Temperaturen ausgesetzt ist, wird bei bestimmten Füllfaktoren inkompressibel und bildet einen ganzzahligen Quanten-Hall (IQH) oder fraktionierten Quanten-Hall (FQH) Zustand. Der $\nu=5 / 2$ Zustand ist einer der aussergewöhlichsten dieser Art, da für ihn nicht-Abelsche Quasiteilchen-Anregungen vorhergesagt wurden. Diese Eigenschaft macht ihn nicht nur hinsichtlich physikalischer Grundlagenforschung interessant, sondern auch für potentielle Anwendungen in topologischen Quantencomputern.

In dieser Arbeit werden die Eigenschaften der IQH und FQH Zustände mittels Transportspektroskopie in zweidimensionalen Elektronengasen, in Quantenpunktkontakten (QPK) und in Quantenpunkten (QP) oder Interferometern untersucht. Ein wichtiges Ziel dieser Arbeit war die Erforschung der Eigenschaften des $\nu=5 / 2$ Zustandes in abgeschlossenen Geometrien und in Tunnelexperimenten. Ein weiteres Ziel war es, Fortschritte zur Realisierung eines Experiments zu erzielen, welches eine Untersuchung der Statistik der Quasiteilchen-Anregungen des $\nu=5 / 2$ Zustandes erlaubt.

Im ersten Teil dieser Arbeit geben wir einen Überblick über die Grundlagen zweidimensionaler Eletronengase und der Quanten-Hall Physik und fassen die wichtigsten theoretischen und experimentellen Erkenntnisse über den $\nu=5 / 2$ Zustand zusammen (Teil I).

Anschliessend diskutieren wir (Teil II) experimentelle Schwierigkeiten die überwunden werden mussten, um die hier präsentierten Experimente durchzuführen. Hierfür wurden ein Mischkryostat-Aufbau und die Probenfabrikation optimiert, und eine neue Verkabelung mit Tieftemperatur-Filtern musste entworfen und implementiert werden. Durch diese Verbesserungen konnten wir einen voll quantisierten $\nu=5 / 2 \mathrm{FQH}$ Zustand beobachten und minimale Elektronentemperaturen von 12 - $13 \mathrm{mK}$ erreichen.

Die räumliche Einschränkung von FQH Zuständen in QPKen ermöglicht die Untersuchung der Tunnel-Eigenschaften dieser Zustände und ist ein erster Schritt in Richtung der Implementierung eines Interferenz-Experiments. Wir diskutieren die Transporteigenschaften von QPKen in Teil III dieser Arbeit. Die Transporteigenschaften sauberer QPKe werden durch Anlegen einer Vorspannung ohne externes Magnetfeld untersucht und ihr Einschlusspotential wird charakterisiert. Durch das Anlegen eines Magnetfeldes und die Variation der QPK Transmission können sich verschiedene IQH und FQH Zustände in den QPKen bilden. Wir diskutieren die Bedeutung von Unordnung und Lokalisierungen und deren Einfluss auf die Transporteigenschaften von QPKen im Regime der IQH und FQH Zustände. Wir zeigen auf wie selbst fragilste FQH Zustände, wie der $\nu=5 / 2 \mathrm{Zu}-$ stand, in QPKen definiert werden können. Dies wurde durch optimierte Gating-Techniken und die Identifikation geeigneter Wachstums- und Dotierschemata ermöglicht. Schliesslich untersuchen wir schwaches Quasiteilchen-Tunneln im zweiten Landau-Niveau, unter Zuhilfenahme dieser Techniken. Die Abhängigkeit des Leitwerts des Quasiteilchen-Tunnelns von Temperatur und Vorspannung ermöglicht es uns Parameter zu extrahieren, die die Randanregungen der FQH Zustände bei $\nu=5 / 2,7 / 3$ und 8/3 charakterisieren. Dies erlaubt einen Vergleich mit theoretisch vorhergesagten möglichen Kandidaten für die Wellenfunktionen dieser Zustände. Unsere Experimente zeigen bei $\nu=5 / 2$ die grösste Übereinstimmung mit den Abelschen (3,3,1)- und $(1,1,3)$ Zuständen, während bei $\nu=8 / 3$ ein Teilchen-Loch konjugierter Laughlin-Zustand am besten mit den Tunnelexperimenten kompatibel ist. 
Übergehend zu Strukturen höherer Komplexität untersuchen wir anschliessend Eigenschaften von QPen und Interferometern im Regime der IQH und FQH Zustände (Teil IV). Wir zeigen wie Ladungdetektions-Techniken an die technologische Grenze geführt werden können. Dies erlaubt uns eine zeitaufgelöste Untersuchung des Tunnelns einzelner Elektronen in mehr als ein Mikrometer grossen QPen, die für Interferenzexperimente geeignet sind. Bei geschlossenen Tunnelbarrieren können Situationen auftreten, in denen die interne Struktur des QPs, aus kompressiblen und inkompressiblen Bereichen, das Ladeenergiespektrum verändert. Wir zeigen wie eine solche Situation in Analogie zum Verhalten eines Doppel-Quantenpunktes verstanden werden kann. In einer weiter geöffneten Konfiguration mit grosser Transmission der Tunnelbarrieren verhält sich dieses System wie ein Coulombdominiertes Fabry-Pérot Interferometer. Anschliessend zeigen wir Fortschritte die in Richtung der Implementierung eines Fabry-Pérot Interferometers bei $\nu=5 / 2$ erzielt wurden. Hierfür haben wir Top-Gate-Strukturen auf drei verschiedenen Wafern untersucht. Die Wafer wurden mit unterschiedlichen Wachstums- und Dotier-Techniken hergestellt. Wir diskutieren experimentelle Herausforderungen und Einschränkungen die durch das Gaten dieser hochbeweglichen Strukturen verursacht werden. Mithilfe optimierter Beleuchtungsund Gating-Techniken gelingt es uns ein Interferometer mit $950 \mathrm{~nm}$ breiten QPKen zu definieren, bei dem der $\nu=5 / 2$ Zustand perfekt transmittiert wird, mit einer Energielücke von mehr als $200 \mathrm{mK}$. Obwohl in den untersuchten Proben keine Interferenzeffekte bei $\nu=5 / 2$ beobachtet werden konnten, zeigen unsere Resultate einen Weg zu einer möglichen experimentellen Implementierung eines Fabry-Pérot Interferometers bei $\nu=5 / 2$ auf.

Abschliessend diskutieren wir Transportmessungen in den Phasen des wiederkehrenden ganzzahligen Quanten-Hall Effektes (RIQH) im zweiten Landau-Niveau (Teil V). In Nichtgleichgewichts-Situationen im Transport, bei denen einige nA DC Strom fliessen, beobachten wir Übergänge von den RIQH Phasen zu einer isotropen, kompressiblen Phase. Aus diesem Übergang extrahieren wir charakteristische Energieskalen für die verschiedenen RIQH Zustände. Überraschenderweise ist der Übergang von den RIQH Phasen zur isotropen kompressiblen Phase qualitativ unterschiedlich für weniger bzw. mehr als halb gefüllte Spin- Äste des zweiten Landau-Niveaus. Dies könnte auf eine gebrochene ElektronLoch Symmetrie hinweisen, oder bedeuten, dass die RIQH Zustände eine komplexere Substruktur besitzen als bisher theoretisch erwartet.

Unsere Resultate liefern wichtige Erkenntnisse über die Physik des zweiten LandauNiveaus und tragen zum Verständnis der FQH Zustände bei $\nu=5 / 2,7 / 3$ und $8 / 3$ bei. 